\title{
ПЕРЕКЛАДИ БІБЛІЇ ТА ЇХНЯ РЕЦЕПЦІЯ У ТВОРАХ ТАРАСА ШЕВЧЕНКА
}

\author{
ОЛЬГА БІГУН \\ Київський національний університет імені Тараса Шевченка, Київ - Україна \\ PRZEKŁADY BIBLII I ICH RECEPCJA \\ W TWÓRCZOŚCI TARASA SZEWCZENKI
}

\section{OLGA BIHUN}

Kijowski Uniwersytet Narodowy im. Tarasa Szewczenki, Kijów — Ukraina

STRESZCZENIE. W artykule przeanalizowano historię i wpływ przekładów Biblii na rozwój ukraińskiego języka literackiego, szczególniena kształtowanie idiostylu T. Szewczenki. Ponadto zwrócono uwagę na estetyczną percepcję inkunabułów w twórczości poety.

\section{THE BIBLE TRANSLATIONS AND THEIR RECEPTION IN TARAS SHEVCHENKO'S WRITINGS}

\author{
OLGA BIGUN \\ Taras Shevchenko Kyiv National University, Kyiv — Ukraine
}

\begin{abstract}
The history and the influence of the Bible translations on the development of literary Ukrainian language is analyzed; this influence found its realization in the direct enrichment of the religious and church vocabulary, as well as in the language reception of the fiction literature. The influence of the Bible translations on the formation of the idiostyle of T. Shevchenko is under study. The aesthetic reception of the incunabula in the poet's works is analyzed.
\end{abstract}

$\mathrm{H}$ а сьогодні тему „Біблія і Шевченко” розглядають у складному комплексі взаємопов'язаних аспектів: загальнокультурологічному, герменевтичному, мовному, дискурсивно-соціологічному, ідентифікаційно-описовому, компаративному, інтерсеміотичному, релігійному тощо. До того ж, кодифікований універсум шевченкових творів щоразу потребує новітніх методів та стратегій. Перспектива досліджень, присвячених багаторівневій рецепції Біблії у творчості Т. Шевченка, передбачає застосування методологічного плюралізму та інтердисциплінарних інтерпретацій, зосередження на авторському контексті 3 культурно-історичним та суспільно-політичним дискурсами, інтелектуальнодуховними та мистецькими візіями.

У книгознавчій площині тексти Святого Письма, якими користувався Т. Шевченко, потребують докладного вивчення. Загальновідомо, що на сьогодні відсутні відомості і про Псалтир, який з дитинства знав поет напам'ять, і про книги Старого Завіту чи Євангелія, що були з ним на засланні.

Оскільки церковнослов'янська мова становила вагомий складник творчості Т. Шевченка, важливо порівняти мовностилістичні та поетикальні особливості існуючих на той час перекладів Святого Письма, з якими міг бути знайомий поет, щоб з'ясувати диференційні ті інтегральні аспекти „символічної” мови, 
закоріненої в специфіку старозавітних чи новозавітних текстів, та їі поліфункціональності у творах Т. Шевченка.

Традиційно переклади Святого Письма церковнослов'янською, як і формування самої мови, прийнято пов'язувати з діяльністю солунських братів Кирила та Мефодія. Однак належить визнати, що духовне, культурне, літературне життя давньої Україні існувало ще до прийняття християнства. Існує припущення, що під час своєї хазарської місії Кирило (Костянтин) зупинявся в Корсуні, де було знайдено Євангеліє і Псалтир, написані руськими письменами - глаголицею, що була близькою до сучасної української мови, а сам місіонер розмовляв 3 людиною, яка говорила руською мовою. Цю корсунську легенду описано у відповідній науковій літературу, однак одностайна думка про руські письмена й книги в Корсуні, з якими познайомився Кирило, відсутня ${ }^{1}$. Після хрещення Русі мовою християнських обрядів стає церковнослов'янська як штучний конструкт - усереднена мова для всіх слов'ян з елементами, запозиченими з мов декількох народностей південних, західних і східних слов'ян, а також із грецької мови. Із численних біблійних кодексів Київської Руси-України від XI ст. збереглося на сьогодні лише 13 пам'яток. Найбільш відомі - це Остромирова Свангелія 1073-1074 років, Ізборники Святослава 1073 і 1076 років, Тирський Псалтир 1078-1087 років, Реймська Свангелія, Архангельська Євангелія, Туровська Євангелія, Чудовський Псалтир (усі датовані другою половиною XI ст.). 3 XII ст. збереглося 28 рукописів; з XIII - 18 великих рукописів i 32 уривки (тут, очевидно, позначилося лихоліття — вторгнення монгольської Золотої Орди та зруйнування столичного Києва в 1240 р.). 3 XIV ст. збереглося 16 кодексів і 35 уривків, а з XV - вже понад 100 великих рукописних текстів ${ }^{2}$. Ця „бібліотека сакральних текстів” замінила собою попередні здобутки духовного розвитку та значно вплинула на формування української етнокультурної спільноти ${ }^{3}$.

Наголосимо й на проблемі констатації факту перекладу Біблії церковнослов'янською, що постала поряд із трьома священними мовами - давньогрецькою, латиною, давньогебрейською. Лексичні й граматичні засади церковнослов'янської мови - мобільність та експресивність дієслівних форм, багатство афіксів і флексій, що не мають аналогій у сучасних мовах, лаконізм і динаміка синтаксичних структур, етимологічна глибина лексики створюють неперевершену глибину духовно-емоційних переживань, ілюзію причетності до сакральних подій. Відтак, сам процес перекладу розраховує на майстерне використання точно й чітко окресленого кола зображальних засобів. „Перекладач, — як переконаний архієпископ Августин, - повинен мати одночасно глибоку філологічну підготовку і неабиякі поетичні дарування. Бо без цього переклад богослужбових книг буде виглядати знебарвленим і буденним переказом великих поем. Крім того, перекладачеві необхідно знати святовітцівське богослов'я, а не схоластичне, щоб зрозуміти глибокі за догматичним змістом літургічні тексти"4. Безперечно, така проблема постала перед тлумачами Святого Письма на інші європейські мови під час Реформації в XV-XVI ст.

${ }^{1}$ О. М иш ан и ч, Крізь віки, Київ 1996, с. 11-12.

${ }^{2}$ М. Жукалюк, Д. Степо вик, Коротка історія перекладів Біблії українською мовою, Київ 2005, c. $14-15$.

${ }^{3}$ Г. Т и мо ш и к, Жіночі гебрайські імена у новочасних перекладах Святого Письма украӥнською мовою, [в:] „Лінгвістичні студії” Донецьк 2009, вип. 19, с. 263.

${ }^{4}$ Арх ієпископ Августин, Церковнослов'янська мова - мова богослужінь, [в:] Християнство й украӥнська мова, Матер. наук. конф., Київ 5-6 жовтня 2000 р., Львів 2000, с. 15. 
Насамперед перекладачі канонічних текстів європейськими мовами французькою, німецькою, англійською, польською, чеською, білоруською, українською - керувалися необхідністю зробити доступним Святе Письмо для широких верств населення, зокрема в Німеччині переклад Нового Завіту був здійснений Мартіном Лютером 1522 р., а 1534 р. німецькою мовою вийшла Біблія. У Британії до перекладу Святого Письма долучився оксфордський учений і письменник У. Тайндел, якого за це було страчено. Роботу над перекладом було завершено 1535 р. його послідовниками. Католицький переклад французькою Нового Завіту був здійснений 1523 р. Жаном Лефевром, а протестантська версія Біблії французькою вийшла 1535 р. за авторства двоюрідного брата Жана Кальвіна П'єра Оліветана. 1551 р. Ж. Кальвін переглянув переклад П. Оліветана і 1553 р. Р. Етьен перевидав Біблію, додавши оригінальну нумерацію віршів. Білоруський переклад Біблії був здійснений Ф. Скориною та виданий частинами в Празі та Вільно в 1515-1525 рр.. Чеською мовою Біблія 3’явилась 1488 р., проте більш точний іiї переклад відомий під назвою Кралицька Біблія, що датується 1593 р.. У польських перекладах Біблії розрізняють переклади, здійснені реформатами (Брест, 1563), католиками (Несвіж, 1572) та протестантами (Гданськ, 1632).

Загальновідомо, що переклад Святого Письма українською стимулювався внутрішніми і зовнішніми чинниками. Окрім бажання наблизити Слово Боже до простого люду, появу канонічних текстів українською зумовила ще одна особливість: на українських землях, як зазначають дослідники, „між письмовими біблійними текстами й усним проповідуванням виникли досить неприємні та небажані „ножиці”. Йдеться про те, що книжково-рукописна традиція Святого Письма зберігалася на малозрозумілій церковнослов'янській мові, усно-проповідницька традиція - на народній”'. Зовнішніми чинниками перекладів Божого Слова українською вважають зразки чеських, польських, білоруських протестантських перекладів Святого Письма. Аналізуючи вплив протестантських перекладів, Л. Шевченко зазначає, що Пересопницьке Свангеліє 1556-1561 рр. використало (але не дослівно) текст лютеранського Нового Завіту Секлюціана 1553 р. (перекладач користувався, крім церковнослов'янського, чеськими й польськими джерелами), Свангеліє В. Тяпинського (біля 1570 р.) переклад соціанського Нового Завіту М. Чеховича 1577 р., Крехівський Апостол (біля 1560-х) - переклад із кальвінської Біблії 1563 р.. 1581 р. з'явилося Євангеліє В. Негалевського, де майже немає слідів церковнослов'янської мови, проте відчувається вплив білоруської й польської мов у лексиці й синтаксисі. Так звана Острозька Біблія, що видана на Волині (1581р.), виявляє в своїй церковнослов'янщині впливи української народної мови ${ }^{6}$. Загалом, упродовж тисячолітньої історії українських перекладів Біблії, як зазначає В. Кононенко, „їхній вплив на розвиток загальнолітературної мови то посилювався, то послаблювався, однак ніколи не припинявся, виявляючи себе як у безпосередньому збагаченні релігійно-церковного лексикону, так і в рецепції мови художньої літератури"7.

Якими ж були найближчі в часі переклади Святого Письма, що могли постати в полі зору Т. Шевченка? І. Дзюба констатує: „В його час не було ще пе-

${ }^{5}$ М. Жукалюк, Д. Степовик, зазн. джерело, с. 14.

6 Л. Ш е в че н ко, Украӥнські переклади Святого Письма на європейському тлі, [в:] “Актуальні проблеми української лінгвістики: теорія і практика" Київ 2003, вип. 7, с. 79.

7 В . Кон о н ен ко, Українські переклади Біблї в розвитку української мови, [в:] Кардинал Йосип Сліпий і сучасність, Івано-Франківськ 2002, с. 150. 
рекладів Біблії українською новолітературною мовою; Житомирська Свангелія 1571 року, староукраїнською книжною мовою, не була йому знайома; користувався він російськими виданнями, що зберігали стилістику церковнослов' янської мови"». Очевидно, згадуючи про цю Євангелію, більш відому під назвою Волинська Євангелія, що є пізнішою версією Пересопницької пам'ятки й містить лише новозавітні тексти, вчений дає зрозуміти, що це джерело могло би стати для Т. Шевченка загальнолексичним орієнтиром уживання поетичної образності чи типової біблійної метафорикия. Достовірно відомо про Біблію в посмертному описі книг Т. Шевченка, де за номером 80 зафіксовано: „Библия, СПб., 1824, 8, 1 кн. с автографом" "10. Згідно завіту самого Т. Шевченка цей примірник був подарований письменниці Маркові Вовчку. Однак 1856 р. Т. Шевченко подарував примірник Біблії Ф. Лазаревському того ж видання 1824 у вісімку, і в ньому є підкреслення олівцем. Відомо, що цей примірник зараз зберігається в НМТШ (№A-214). Учені переконані, що ,за текстом це видання 1824 - найближче повторення Слизаветинської Біблії (1751). Її канонічний, як на той час, церковнослов'янський текст постав у вигляді послідовного опрацювання списку Генадіївської Біблії (1499) вченими-редакторами Острозької Біблії (1583) та кількома генераціями київських учених-монахів. Видрукуване у вісімку дрібним шрифтом, видання 1824 було найзручнішим для того кочового життя, що судилося Т. Шевченкові, а практична відсутність гравюр-ілюстрацій, не нав'язуючи сприйняття тексту художником, сприяла вільній мистецькій інтерпретаціï'"11.

Збірний, дещо ідеальний образ Книги Книг подає Т. Шевченко у своїй повісті Варнак. Це було видання „в красном сафьяновом переплете, с золотыми вытиснутыми и почерневшими украшениями. Это была Библия (как я после узнал) - изящное киевское издание 1743 [года], с высокопарным посвящением гетману Разумовскому"12. Як бачимо, особливого значення тут набуває титульна сторінка. Подібне оформлення притаманне українській друкованій книзі XVII-XVIII ст., стилістика якої продовжує традиції, закладені львівською, острозькою, київською друкарнями ще в попередній період. „Неодмінні атрибути титульної сторінки, - відмічає Я. Ісаєвич, — назва книжки, набрана великими літерами, і вихідні дані, обрамлені дереворитною оздобною рамкою — „фортою”, що в ранніх виданнях має вигляд архітектурного порталу. 3 часом до чисто архітектурних колон стали додавати оздобний рослинний орнамент, - iнколи бічні колони обплетені виноградною лозою. Архітектурна рамка доповнюється клеймами із зображеннями святих або свят, алегоричних композицій. Новим елементом у розвитку титульного аркуша були рамки без фронтону, замість нього центральну частину сторінки оточувала складна композиція, в якій численні клейма з'єднувалися бароковими гірляндами з листям, квітами, плодами. В деяких виданнях Києво-Печерської лаври в нижній частині титульної арки вміщували зображення головного лаврського храму Успенського собору. Трапляються форти, що своєю структурою нагадують іконостас: відповідним чином розміщені гравюри з орнаментальним обрамленням, що відповідало іко-

${ }^{8}$ I. Дз ю ба, Тарас Шевченко. Життя і творчість, Київ 2008, с. 286.

9 Я. Гараси м, Псалми Тарасові: етноканонізація біблійного жанру, [в:] „Вісник Луганського національного університету: Філологічні науки” 2012, № 12, ч. 2, с. 26.

${ }^{10}$ В. Ан ісо в, С. С ер еда, Літопис життя і творчості Т. Г. Шевченка, Київ 1976, с. 343.

${ }^{11}$ С. Р о с о в ец ь к й й, Біблія і Шевченко, [в:] Шевченківська енциклопедія в 2 m., Кийв 2012, T. 1, c. 415.

${ }^{12}$ Т. Ш е в чен ко, Повне зібрання творів в 12 m., Київ 2003, т. 3, с. 124. 
ностасній різьбі. Утім, у середині XVIII ст. до ряду гарно оформлених літургійних видань повертається класична архітектурна рамка-портал"13.

У художньому описі біблійного видання Т. Шевченко чітко передає графічні закони оформлення, притаманні тій культурно-історичній добі. Однак рік видання, вказаний автором, ставить багато запитань: у реєстрі друкарні Києво-Печерської Лаври видання, згадуване в повісті, не значиться, а найближче - за 1758 рік не має зазначеної присвяти ${ }^{14}$. Я. Ісаєвич пише, що це видання повторювало опрацьовану українськими книжниками Єлизаветинську Біблію 1751 р., в основі якої лежала Московська Біблія 1663 р., а та, відповідно, як наголошувалося в іiї передмові, була лише передруком „с готоваго перевода князя Константина Острожскаго печати неизменно, кроме орфографии и некоторых вмале имен и речений”. Передруки тексту Острозької Біблії сприяли тому, що вжитий у ній варіант церковнослов' янської мови став найавторитетнішим ${ }^{15}$.

Окремо вкажемо на уявну присвяту. Якщо осмислити роки життя Кирила Розумовського (1728-1803), то з'ясується, що присвятили цю Біблію йому в п’ятнадцятирічному віці, ще далеко не гетьману. Це можна вважати неточністю, однак, зважаючи на глибинні символічні коди ${ }^{16}$ Шевченкової творчості, спрямуємо зусилля на їх часткове розшифрування. Ймовірно, так поет натякає на неіснуюче видання Біблії, історію якого, безперечно, знали свідомі українці. Таким виданням міг бути так і не здійсненний задум Петра Могили - вшанування 70-ліття виходу першої друкованої Острозької Біблії. Це мало би бути київське видання Біблії за 1651 р.. Відомо, що митрополит Петро доручив ченцю-граверу Іллі виготовити близько 500 ілюстрацій для майбутнього видання Біблії. Значна частина проекту була здійснена в першій половині 40-х років XVII ст. На жаль, на початку січня 1647 р., у 50-літньому віці, після короткочасної хвороби Петро Могила помер. У зв'язку зі смертю Петра Могили проект Біблії так і не був здійснений. Були ще й інші обставини, відомі у вітчизняній історії як „епоха руїни”. Від проекту Петра Могили залишилося понад 130 гравюр на біблійні теми - ілюстрації до перших книг Старого Завіту. Гравер Ілля, вирішивши, що видання Біблії не здійсниться, припинив ілюстрування Святого Письма на Книгах Царів. Гравюри Іллі збереглися до наших днів; нині їх вивчають богослови та мистецтвознавці ${ }^{17}$. Невідомо, де зберігалися ці гравюри під час шевченкового перебування в Києві і чи міг він їх бачити. Але, знаючи потяг Т. Шевченка до мистецтва гравюри, можна припустити, що саме роботи гравера Іллі надихнули його описати нездійсненний проект Петра Могили в повісті Варнак. Зауважимо, що опис книги закцентовано на іiї зовнішньому вигляді, можливо, так проявилась домінанта естетичного сприйняття стародруку, що репрезентувала малярське покликання Т. Шевченка.

Щодо перекладів Біблії, сучасних Кобзареві, відомо про спробу перекласти Євангелії новоукраїнською мовою у к. 30-х або на поч. 40-х pp. XIX ст. письменником-галичанином М. Шашкевичем. Зберігся рукопис його перекладу чотирьох глав Свангелія від Матвія ${ }^{18}$. У 60-х рр. повний переклад Свангелія

${ }^{13}$ Я. І с ає в ич, Украйнське книговидання: витоки, розвиток, проблеми, Львів 2002, с. 324.

${ }_{14}$ Я. Зап аско, Я. Іс ає в ич, Пам'ятки книжкового мистеитва. Каталог стародруків, виданих на Украӥні, Львів 1984, кн. 2, ч. 1, с. 107.

${ }^{15}$ Я. І с а є в ич, зазн. джерело, с. 320.

${ }^{16}$ G. Grabowicz, The Poet as Mythmaker. A Study of Symbolic Meaning in Taras Ševčenko, Cambridge 1982, p. 16.

${ }_{17}^{17}$. Жукалюк, Д. Степ овик, зазн. джерело, с. 28.

${ }_{18}$ В. Н н м ч у к, Українські переклади Святого Письма, [в:] Das Ukrainische als Kirchenspraсhе. Украӥнська мова в Церквах, Wien 2005, с. 17. 
здійснив П. Морачевський, однак через консерватизм російської синодальної цензури публікація видання була відкладена. Переклад П. Морачевського розповсюджувався в рукописних копіях. I лише 1906 р. завдяки новим історичним змінам, що прийшли з революцією 1905 р. до Росії, цей переклад отримав дозвіл на друк від Синоду Російської Православної Церкви. На переконання ученихфілологів того часу (О. Востокова, О. Никитенка, I. Срезневського, П. Житецького), „Евангеліе, переведенное на малороссійское нарьчіє г. Мораческимъ, есть въ высшей степени трудъ зам ъчательный и съ учено-филологической стороны, и со стороны религіозно-нравственной" 19 . Проте колоніальне становище України затримувало український книгодрук, і Слово Боже до українського народу дійшло зі значним запізненням.

Ідея перекладу Святого Письма українською була особливо популярною і серед членів Кирило-Мефодіївського братства, де обговорювалися ідеї так званих недільних шкіл з викладанням предметів українською мовою й вивчення рідною мовою Закону Божого. До того ж, україномовні переспіви Псалмів, сюжети з Псалтиря все частіше набували поетичних форм у творах П. ГулакаАртемовського, П. Куліша, М. Максимовича, Т. Шевченка. Право українського народу на свою мову, літературу, історію взялися відстоювати засновники — колишні члени Кирило-Мефодіївського братства — й прихильники з числа національно свідомої інтелігенції першого поважного часопису „Основа”, що виходив у Петербурзі з 1861 р. Саме зі сторінок цього часопису вперше було повідомлено читачів про створення в Петербурзі Громадського комітету для збору коштів на видання підручників і Святого Письма українською мовою ${ }^{20}$. Саме 3 цієї натхненної атмосфери входження живої української мови у всі сфери життя, включно з сакральною цариною Божого Слова, виніс П. Куліш своє переконання в необхідності перекладу Біблії, що через численні перешкоди та невдачі з допомогою I. Пулюя та І. Нечуй-Левицького була надрукована у Відні (1903 p.).

Незважаючи на те, що творча скарбниця Т. Шевченка нараховує переклади 11 псалмів, Біблію поет волів цитувати церковнослов'янською. Принаймні, поет ніде не висловлював ідеї створення Біблії українською мовою. Уважаємо, що канонічні тексти церковнослов'янською для Т. Шевченка були знаковою системою причетності до культури, освіти й літератури. Це можна назвати своєрідним потягом до „архаїки” та пояснити тим, що в умовах зростання етнічної свідомості виникала потреба шукати „свою античність”, корені власної самобутності ${ }^{21}$, староукраїнська / церковнослов'янська була не тільки мовою біблійних текстів, але й мовою давньої української літератури, складовою лексики та фразеології дум, використовувалась як мова „книжна” для вкладання історичних довідок, документів та свідчень, з якими поет стикався, наприклад, під час роботи в Археографічній комісії (1845-1847). Дослідники зауважують, що під час перебування в комісії Т. Шевченко найбільше цікавився пам'ятками давнини. В обов'язки художника входило не тільки малювання цих пам'яток, а й збирання різних документів тощо. „Робота в комісії, — переконаний В. Микитась, - була Шевченкові до душі, бо він завжди виявляв великий інтерес до історії і археології, яку називав „таинственной матерью ис-

${ }^{19}$ В. Науменко, Ф. С. Морачевській и его литературная дњятельность, Кіевъ 1903, с. 33. c. 644 .

${ }^{20}$ Енциклопедія історії України в 12 m., редкол. В. А. Смолій (голова) та ін., Київ 2010, т. 7,

${ }^{21}$ Я. І І ає в ич, Мовний код культури в 2 т., [в:] Історія украӥнської культури, Київ 2001, т. 2, с. 159 . 
тории". Крім того, це давало йому можливість завжди бути серед народу, вивчати його звичаї. Перебуваючи на Переяславщині і в Чернігові, Т. Шевченко пише свої „археологічні замітки” й складає науковий опис старих книг з Переяслава й Чернігова, записує велику кількість зразків народної творчості”"22. Очевидно, у тих документах були й зразки давньої української писемності. Відомо, що київська Археографічна комісія багато зробила щодо видання пам'яток давнини: були опубліковані літописи Самовидця, Граб'янки, Величка, що стали грунтом для творчої інтерпретації багатьох історичних подій у творах Т. Шевченка. У поетико-стилістичній площині шевченкових творів, як уважає I. Дзюба, поетові „довелося творити високий патетичний стиль нової української мови (якого не було до нього і в романтиків), беручи староукраїнізми з літописів, „Слова о полку Ігоревім”, народних релігійних співів, кантів, колядок та українізуючи церковнослов'янські біблеїзми, вводячи їх в українські синтаксичні конструкції, асимілюючи морфологічно, максимально використовуючи можливості українського словотворення" ${ }^{\prime 23}$.

Т. Шевченко не розглядав церковнослов'янську мову як чужорідну, а активно долучав її словотворче багатство до новоукраїнської літературної мови. Як зазначає М. Москаленко, „переклади Шевченка, та й не лише його, з церковнослов'янської та книжної української на живу українську мову в XIX столітті аж ніяк не були перекладами 3 „чужого” на „своє”. Адже, крім церковної літератури, природним носієм якої було духівництво і до якої так чи інакше прилучалися прості люди, селяни, те середовище письменного і неписьменного люду, в якому народився і виріс Шевченко, — в народі побутували напрацьовані попередніми віками численні писемні та усні твори: апокрифи, житія, легенди, бувальщини, перекази духовного та мирського зміст <... . Переклади Шевченка 3 церковнослов'янської - це пряме й закономірне продовження „масового письменства” того часу. Це саме повною мірою стосується й наслідувань (,подражаній”), варіацій та переробок біблійних, у тому числі євангельських мотивів і сюжетів”24. Уважаємо, що причиною цьому є світоглядно-естетична співмірність текстів Святого Письма та морально-світоглядних й етико-естетичних відчуттів Т. Шевченка, втілених у макрокосмічній символіці його поетичної творчості.

${ }^{22} \mathrm{~B}$. М ик итась, До питання про традииї давньої украӥнської літератури в творчості Шевченка, [в:] Збірник прачь восьмої наук. шевченків. конф., Київ 1960, с. 36.

${ }^{23}$ I. Д з юб а , зазн. джерело, с. 286.

${ }^{24}$ М. Моска ленко, Нариси історії українського перекладу, [в:] „Всесвіт”, 2006, № 3-4, c. 46 . 